\title{
Triple Fusion in the Primary Dentition from Law's Site, Alabama (1MS100): A Case Report
}

\author{
Brian D. Padgett \\ Frankfort, KY
}

ABSTRACT Dental fusion of the primary dentition is a rare congenital anomaly. Evidence in the literature of bioarchaeology is scarce. Burial MS100-14 was recovered from Law's Site on Pine Island, in Marshall County, Alabama. Analysis of the remains found that MS100-14

Dental fusion of the primary dentition is a rare congenital anomaly. Examples in the literature of bioarchaeology are exceedingly scarce. Skeletal remains of an infant from the Law's Site (1MS100), in Marshall County, Alabama, presents a clear case of triple fusion of the primary dentition. This is a highly unusual condition, and thus a significant find for the fields of dental anthropology and bioarchaeology.

\section{LITERATURE REVIEW}

Examples of dental fusion in the anthropological literature are uncommon, and texts on dental anthropology, developmental osteology, and paleopathology give the topic little or no attention (Aufderheide and RodríguezMartín, 1998; Hillson, 1996; Ortner, 2003; Scheuer and Black, 2000). Two fused deciduous mandibular incisors are shown in Figure 1.1 of The Anthropology of Modern Teeth (Scott and Turner, 1997: 5), but neither the defect nor the provenance of the specimen is discussed in detail. A rare "talon cusp" found on a deciduous lateral incisor was the primary topic of a case report of a juvenile skeleton excavated in England, though the report states that "the affected incisor also shows abnormal widening, probably representing a double tooth", and mentions the presence of a supernumerary permanent incisor (Mays, 2004:206). It is unclear if this "double tooth" is an actual case of dental fusion, or a case of gemination, defined as the unsuccessful or incomplete division of one tooth germ into two (Canut Brusola, 1988; Oliván Rosas et al. 2004). Some authors agree that distinction between fusion and gemination can sometimes be confusing, and the term "double teeth" should be used when the diagnosis is inconclusive (Andlaw and Rock, 1999; Gonzalez Marquez and Mendez-Nuñez, 1993; Killian and Croll, 1990; Oliván Rosas et al., 2004; Uys and Morris, 2005).

Although there is little in anthropological sources concerning the topic of dental fusion, there have been some relevant clinical studies on modern populations, and some patterns have been documented regarding this dental anomaly. These clinical studies agree that fusion in the primary dentition usually affects two teeth presented a clear case of triple fusion of primary dentition in the maxilla. This appears to be the first case of triple fusion reported from among prehistoric Native American remains in the Southeastern United States. Dental Anthropology 2010;23(1):25-27.

unilaterally in the mandibular arch, and most often in the anterior region; that is, either two incisors, an incisor and a canine, or a supernumerary tooth fused with an incisor (Barberia et al., 2001; Cheng et al., 2003; Favalli et al., 1998; Modrizuki et al., 1999; Oliván Rosas et al., 2004; Yonezu et al., 1997).

Studies among European, (Asian) Indian, and Turkish populations reveal a prevalence of less than $1 \%$ for double fusion in primary dentition (Aquiló et al., 1999; Barberia Leache and Boj Quesada, 2001; Boj Quesada 1990; Bruce et al., 1994; Erdem et al., 2001; Reddy and Munshi, 1999). North American populations have a prevalence ranging from 0.14 to 3\% (Hagman, 1988). A study in Shenyang city, China, reported $1.52 \%$ prevalence among children there (Cheng et al., 1999). The prevalence appears to be highest in Japan, where 4.1 to $5 \%$ of children studied presented this anomalous feature, and unlike other populations, there was a tendency regarding sex, as a significantly higher proportion of boys displayed congenital dental fusion (Modrizuki et al., 1999; Yonezu et al., 1997).

As rare as double fusion appears to be, it is not surprising that triple fusion of primary dentition is even less common. In the study of Indian children $(n=4,205)$, there was no case of triple fusion (Reddy and Munshi, 1999), though a separate team from India reports the case of a child with triple fusion involving two ipsilateral incisors and a supernumerary tooth (Prabhakar et al., 2004). Among Chinese children studied ( $\mathrm{n}=4,286)$, only one case of triple fusion was found, involving two ipsilateral incisors and the adjoining canine (Cheng et al., 1999). The prevalence of "triplication of primary teeth" among Turkish children was stated as $0.02 \%$ (Erdem et al., 2001).

Problems associated with the congenital fusion of primary dentition may include an increased susceptibility to caries in the fused teeth (Reddy and Munshi, 1999).

Correspondence to: Brian D. Padgett, 313 Juniper Drive, Frankfort, KY 40601

E-mail: boneyard90@hotmail.com 

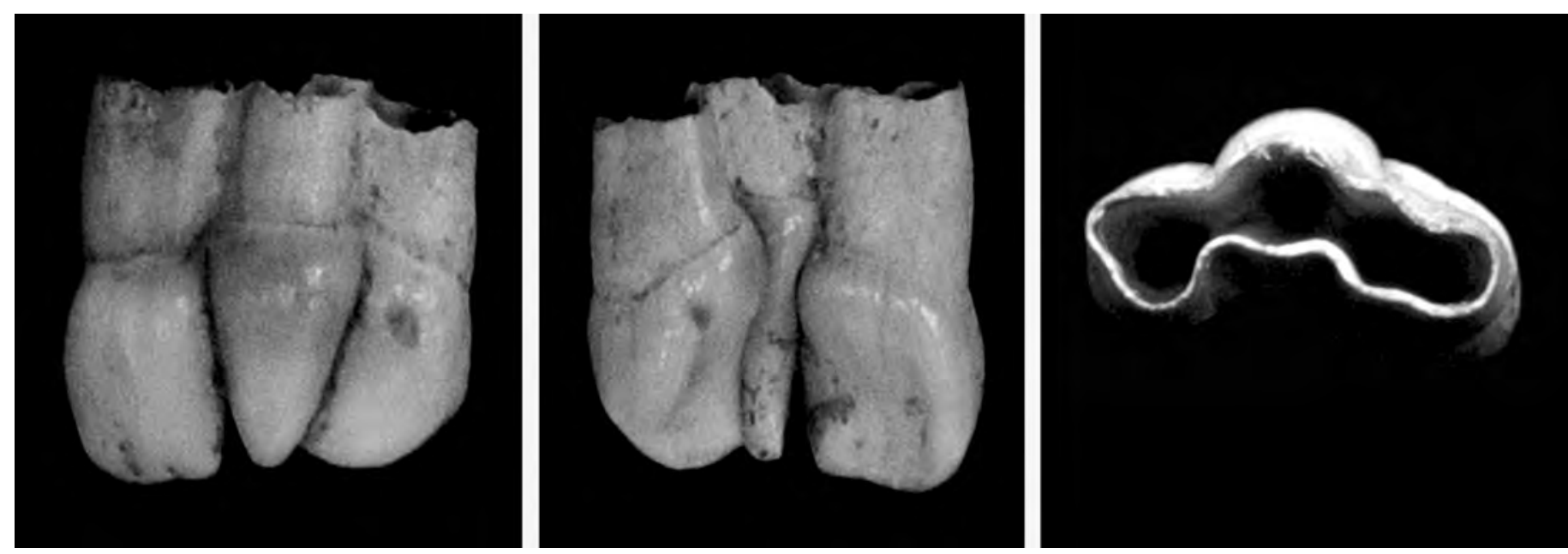

Fig. 1. Fused teeth of Burial MS100-14. (Left) Labial view with the left primary central incisor (i1) to the left of the photograph, a conical lateral incisor (i2) in the center, and the canine (c) to the right. (Center) Lingual view of the fused teeth, with c to the left and i1 to the right. (Right) Alveolar (apical) view of the formative roots with c to the left and i1 to the right of the photograph.

There is also an association between fusion of primary dentition and agenesis of the corresponding permanent teeth; with regard to this condition, various authors cite percentages of incidence ranging from 20 to $75 \%$, the occurrence of which may depend on which teeth are fused (Aquiló et al., 1999; Barberia Leache and Boj Quesada, 2001; Boj Quesada 1990; Canut Brusola 1988; Oliván Rosas et al., 2004; Ostos Garrido and Peñalva Sanchez, 1996; Hagman, 1988; Reddy and Munshi, 1999).

\section{MATERIALS AND METHODS}

A standard osteological analysis was performed on the skeletal remains recovered from Law's Site (1MS100). The Law's Site was a village on the southern end of Pine Island in Marshall County, Alabama. The site was excavated in 1938 by the Works Project Administration (WPA) under the direction of Carl F. Miller (Webb and Wilder, 1951). Shortly thereafter, Pine Island was inundated when construction of Guntersville Dam was completed and the low-lying Guntersville Basin flooded to become Guntersville Lake.

The site had seen Native American occupation since the Archaic Period (about 8,000-1,000 B.C.) (Walthall, 1980); though many of the burials have been convincingly attributed to the post-contact period, between 1540 and about 1715 (Fleming, 1976; Padgett, 2007; Webb and Wilder, 1951). It is believed that the Native occupants of this latter period were the historically known Koasati, or Coushatta, tribe (Padgett, 2007; Swanton, 1985, 1989), though there is some dispute on this issue (Hudson, 1997).

\section{CASE REPORT}

Burial MS100-14 was an infant of indeterminate sex, aged about 9 months based on dental eruption. No indications of pathological infection or physical trauma were found among the remains.
Burial MS100-14 exhibited fused dentition, appearing as a block of three teeth fused side by side in their standard position. The fused set consists of the deciduous left maxillary central incisor, lateral incisor, and canine (Fig. 1). The central incisor and canine appear to be of normal dimensions, while the lateral incisor is reduced in mesiodistal width, and appears to be a conically-shaped "peg tooth."

\section{DISCUSSION}

The three teeth are fused at both the enamel and the dentin, though all three can be recognized as distinct from the others (Fig. 1). Furthermore, it is apparent that although the pulp cavities of the three teeth are continuous with each other, each tooth was maintained by its own root canal. These observations support the assertion that this is a true case of dental fusion, rather than gemination of a single tooth (Oliván Rosas et al., 2004; Uys and Morris, 2005).

Some studies have found a predilection for one sex or the other regarding fused teeth or peg teeth (Wu and Feng 2005; Yonezu et al., 1997); however, no evidence relating to sex can be interpreted from the remains or associated materials of Burial MS100-14.

\section{CONCLUSION}

The expression of triple fusion in MS100-14 as a dental anomaly is unusual in that it occurred among the maxillary dentition, as other researchers have found that when dental fusion occurs it is predominantly in the mandibular arch (Cheng et al., 2003; Yonezu et al., 1997). The peg-shaped tooth, while an anomalous feature, is typical in the respect that it is a lateral incisor $(\mathrm{Wu}$ and Feng, 2005). Burial MS100-14 represents a rare case in physical anthropology of triple fusion of primary dentition found in an archaeological context. Furthermore, the case 
of MS100-14 is significant as it appears to be the first case of triple fusion reported from among prehistoric Native American remains in the Southeastern United States.

\section{LITERATURE CITED}

Andlaw RJ, Rock WP. 1999. Manual de odontopediatría. Mexico City: McGraw-Hill Interamericana.

Aquiló L, Gandia JL, Cibrian R, Catala M. 1999. Primary double teeth: a retrospective clinical study of their morphological characteristics and associated Anomalies. Int J Pediatric Dent 9:175-183.

Aufderheide AC, Rodríguez-Martín C. 1998. The Cambridge encyclopedia of human paleopathology. Cambridge: Cambridge University Press.

Barberia Leache E, Boj Quesada JR. 2001. Odontopediatría, 2nd ed. Barcelona: Masson.

Boj Quesada JR. 1990. Dientes Dobles. Archivos Odontología 6:321-325.

Bruce C, Manning-Cox G, Stanback Fryer C, Banks K, Gilliam M. 1994. A radiographic survey of dental anomalies in black pediatric patients. NDA J 45:6-13.

Canut Brusola JA. 1988 Ortodoncia Clínica. Barcelona: Salvat.

Cheng RB, Chen X, Liu SJ, Pan L, Wu XG. 2003. [An epidemiological survey on fusion of deciduous teeth of 4286 kindergarten children in Shenyang City.] Shanghai Kou Qiang Yi Xue. (Shanghai J Stomatology) 12:424-426. Translated from Chinese.

Erdem GB, Uzamis M, Olmez S, Sargon MF. 2001. Primary incisor triplication defect. ASDC J Dent Child 68:322325.

Favalli O, Webb M, Culp J. 1998. Bilateral twinning: report of case. ASDC J Dent Child 65: 268-271.

Fleming VK, Jr. 1976. Historic aboriginal occupation of the Guntersville Basin, Alabama. M.A. thesis, Department of Anthropology, University of Alabama, Tuscaloosa.

Gonzalez Marquez MI, Mendez-Nuñez M. 1993. Problemas de nomenclatura en alteraciones morfológicas dentarias. Archivos Odontoestomatología 9:197-204.

Hagman FT. 1988. Anomalies of form and number, fused primary teeth, a correlation of the dentitions. ASDC J Dent Child 55:359-361.

Hillson S. 1996. Dental anthropology. Cambridge University Press, United Kingdom.

Hudson C. 1997. Knights of Spain, Warriors of the Sun: Hernando de Soto and the South's ancient chiefdoms. Athens, GA: University of Georgia Press.

Killian CM, Croll TP. 1990. Dental twinning anomalies: the nomenclature enigma. Quintessence Int 21:571-576.

Mays S. 2004. Talon cusp in a primary lateral incisor from a Medieval child. ASDC J Dent Child 71:206-208.

Modrizuki K, Yoneku T, Yakushiji M, Machida I. 1999. The fusion of three primary incisors: report of case. ASDC J Dent Child 66:421-425.
Oliván Rosas G, López-Jiménez J, Giménez-Prats MJ, Piqueras-Hernández M. 2004. Considerations and differences in the treatment of a fused tooth. Medicina Oral 9:224-228.

Ortner DJ. 2003. Identification of pathological conditions in human skeletal remains, 2nd ed. San Diego: Academic Press.

Ostos Garrido MJ, Peñalva Sanchez MA. 1996. Dientes dobles asociados a inclusión dentaria: posibilidades terapéuticas. Odontología Pediátrica 5:91-96.

Padgett BD. 2007. Islands in the River of Time: the bioarchaeology of two village sites (1MS32 and 1MS100) in Marshall County, Alabama, with new interpretations of the ethnohistoric and archaeological records. M.A. thesis, Department of Anthropology, University of Alabama, Tuscaloosa.

Prabhakar AR, Marwah N, Raju OS. 2004. Triple teeth: case report of an unusual fusion of three teeth. ASDC J Dent Children 71:206-208.

Reddy NN, Munshi AK. 1999. Fusion of primary incisors - a report of six cases. J Indian Soc Pedod Prev Dent 17:55-60.

Scheuer L, Black S. 2000. Developmental juvenile osteology. San Diego: Academic Press.

Scott GR, Turner CG II. 1997. The anthropology of modern human teeth: dental morphology and its variation in recent human populations. Cambridge: Cambridge University Press.

Swanton JR. 1985. Final Report of the United States De Soto Expedition Commission. Smithsonian Institute Press, Washington, D.C. Originally published 1939, U.S. Government Printing Office, Washington, D.C.

Swanton JR. 1987. The Indians of the Southeastern United States. Reprinted. Smithsonian Institute Press, Washington, D.C. Originally published 1946, U.S. Government Printing Office, Washington, D.C.

Uys H, Morris D. 2005. "Double" teeth-a diagnostic conundrum. Dental Update 32:237-239.

Walthall JA. 1980. Prehistoric Indians of the Southeast: Archaeology of Alabama and the Middle South. Tuscaloosa, AL: University of Alabama Press.

Webb WS, Wilder CG. 1951. An archaeological survey of Guntersville Basin on the Tennessee River in Northern Alabama. Lexington, KY: University of Kentucky Press.

Wu H, Feng HL. 2005. [A survey of number and morphology anomalies in permanent teeth of 6,453 youths between 17 to 21 years old.] Zhonghua Kou Qiang Yi Xue Za Zhi [Chinese J Stomatology] 40:489490. Translated from Chinese.

Yonezu T, Hayashi Y, Sasaki J, Machida Y. 1997. Prevalence of congenital dental anomalies of the deciduous dentition in Japanese children. Bull Tokyo Dental College 38:27-32. 